\title{
ASSOCIATION BETWEEN LEVELS OF SPORTS PARTICIPATION AND ORAL INJURIES AMONG COMBAT ATHLETES
}

\author{
ASSOCIAÇÃO ENTRE NIVEIS DE PARTICIPAÇÃO NO ESPORTE ELESÕES ORAIS EM ATLETAS DE COMBATE \\ ASOCIACIÓN ENTRE NIVELES DE PARTICIPACIÓN EN EL DEPORTE Y LESIONES ORALES EN ATLETAS \\ DE COMBATE
}

\section{Maryam Hadizadeh' (D) \\ (Sports Injuries) \\ Illiya Dalila Mohd Azri ${ }^{1}$ (D) \\ (Exercise Science) \\ Hamidreza Mohafez ${ }^{2}$ (D) \\ (Statistician) \\ Eliza Binti Hafiz' (ID \\ (Physical Therapist) \\ Yasuhiro Sugajima3 ${ }^{3}$ (D) \\ (Traumatology)}

Muhammad Danial Mohd Azri' (ID (Exercise Science)

1. University of Malaya, Centre for Sport and Exercise Sciences, Kuala Lumpur, Malaysia.

2. University of Malaya, Faculty of Engineering, Department of Biomedical Engineering, Kuala Lumpur, Malaysia.

3. Asahi University, School of Health Sciences, Department of Health and Sports Sciences, Mizuho, Japan.

\section{Correspondence:}

Maryam Hadizadeh. Centre for

Sport and Exercise Sciences,

University of Malaya. Jalan

Universiti, 50603. Kuala Lumpur.

Malaysia.mary@um.edu.my

\begin{abstract}
Introduction: Oral injuries are common traumas in combat sports due to the aggressive nature of both offense and defense. Sports mouth guards are made to reduce the risk of traumatic face and jaw injuries and concussions during sports activities. Objective: The objective of this study was to determine the prevalence of oral injuries in combat sports and to examine the association between participation levels and percentage of injury occurrence. Methods: One hundred and eight participants (mean age: $22.42 \pm 2.162$ years) who were involved in sparring events were recruited. Data were collected using a questionnaire consisting of 22 questions about the demographic profile of the athletes, their injury experience and type of injuries sustained, awareness and use of mouth guards in sports activities. Descriptive analysis, Chi-square test, and one-way analysis of variance (ANOVA) were applied for data analysis. Results: Almost $77 \%$ of participants had experienced oral injuries during sports activities and nearly $90 \%$ were aware that oral injuries can be reduced by using mouth guards. In addition, $52.7 \%$ of participants complained that the mouth guard is not comfortable to use during sports activities. Findings revealed a significant moderate association between levels of participation and number of oral injuries $(p=0.013)$. One-way ANOVA showed a significant mean difference in the rate of oral injury for the four levels of participation groups $F(3,104)=6.21, p=0.011$. Post-hoc comparisons using the Bonferroni test indicated a significant mean difference between university-state levels $(p=0.033)$ and university-national levels $(p=0.028)$. Conclusion: This study revealed that higher levels of participation in sports have a higher risk of injury. It was also found that the discomfort of using a mouth guard can be reduced if the coaches make the athletes wear proper mouth guards that follow the recommended specifications. Level of evidence IIIb; Case control study.
\end{abstract}

Keywords: Oral injury; Combat sports; Sports participation levels; Sports mouth guard.

\section{RESUMO}

Introdução: As lesões orais são traumas comuns nos esportes de combate, devido à natureza agressiva tanto do ataque quanto da defesa. Os protetores bucais esportivos são feitos para diminuir o risco de lesões traumáticas na face e na mandibula; e também de concussão durante as atividades esportivas. Objetivo: Este estudo teve como objetivo determinar a prevalência de lesões orais em esportes de combate e examinar a associação entre níveis de participação e a porcentagem de ocorrência de lesões. Métodos: Foram recrutados cento e oito participantes (média de idade: 22,42 $\pm 2,162$ anos) envolvidos em eventos de combate. Os dados foram coletados por meio de um questionário composto por 22 perguntas sobre o perfil demográfico dos atletas, sua experiência com lesões e tipo de lesões sofridas, conhecimento e uso de protetores bucais em atividades esportivas. A análise descritiva, o teste do qui-quadrado e a análise de variância (ANOVA) foram aplicados para análise dos dados. Resultados: Quase 77\% dos participantes sofreram lesões orais durante atividades esportivas e quase $90 \%$ estavam cientes de que as lesões orais podem ser reduzidas com o uso de protetores bucais. Além disso, 52,7\% dos participantes reclamaram que o protetor bucal não é confortável para uso durante as atividades esportivas. Os achados revelaram associação moderada significativa entre niveis de participação e número de lesões orais $(p=0,013)$. A ANOVA unilateral mostrou uma diferença média significativa na taxa de lesão oral nos quatro niveis dos grupos de participação $F(3,104)=6,21, p=0,011$. As comparações post-hoc usando o teste de Bonferroni indicaram diferença média significativa entre os niveis universitário-estadual ( $p=0,033)$ e os níveis universitário-nacional $(p=0,028)$. Conclusão: Este estudo revelou que níveis mais altos de participação no esporte representam maior risco de lesões. Verificou-se também que a sensação de desconforto ao usar protetor bucal pode ser reduzida se os treinadores fizerem com que os atletas usem protetores bucais adequados, que sigam as especificações recomendadas. Nível de evidência IIIb; Estudo Caso-Controle.

Descritores: Lesão oral; Esportes de combate; Níveis de participação esportiva; Protetor bucal esportivo.

\section{RESUMEN}

Introducción: Las lesiones orales son traumas comunes en los deportes de combate, debido a la naturaleza agresiva tanto del ataque como de la defensa. Los protectores bucales deportivos son hechos para disminuir el riesgo de lesiones traumáticas en el rostro y en la mandíbula; y también de concusión en las actividades deportivas. 
Objetivo: Este estudio tuvo como objetivo determinar la prevalencia de lesiones orales en deportes de combate y examinar la asociación entre los niveles de participación y el porcentaje de ocurrencia de lesiones. Métodos: Fueron reclutados ciento ocho participantes (promedio de edad: 22,42 $\pm 2,162$ años) involucrados en eventos de combate. Los datos fueron colectados a través de un cuestionario compuesto por 22 preguntas sobre el perfil demográfico de los atletas, su experiencia con lesiones y tipo de lesiones sufridas, conocimiento y uso de protectores bucales en actividades deportivas. El análisis descriptivo, el test de chi-cuadrado y el análisis de varianza (ANOVA) fueron aplicados para el análisis de los datos. Resultados: Casi 77\% de los participantes sufrió lesiones orales durante las actividades deportivas y casi $90 \%$ tenía conocimiento de que las lesiones orales pueden ser reducidas con el uso de protectores bucales. Además, 51,7\% de los participantes reclamaron que el protector bucal no es confortable para uso durante las actividades deportivas. Los hallazgos revelaron asociación moderada significativa entre niveles de participación y número de lesiones orales $(p=0,013)$. El ANOVA unidireccional mostró una diferencia promedio significativa en la tasa de lesión oral en los cuatro niveles de grupos de participación $F(3,104)=6,21, p=0,011$. Las comparaciones post hoc usando el test de Bonferroni indicaron una diferencia promedio significativa entre los niveles universitario-estatal $(p=0,033)$ y los niveles universitario-nacional $(p=0,028)$. Conclusión: Este estudio reveló que niveles más altos de participación en el deporte representan mayor riesgo de lesiones. Se verificó también que la sensación de incomodidad al usar protectores bucales adecuados puede reducirse si los entrenadores hacen con que los atletas usen protectores bucales adecuados, que sigan las especificaciones recomendadas. Nivel de evidencia IIIb; Estudio Caso-Control.

\section{Descriptores: Lesión oral; Deportes de combate; Niveles de participación deportiva; Protector bucal deportivo.}

\section{INTRODUCTION}

Trauma from sports has been increasing recently because of the people rising trend towards exercise and physical fitness. A large number of dental injuries have been reported during sports activities involving the hard and soft tissues area like avulsed, chipped or luxated teeth, jaws fracture, and also lip laceration and injuries to the tongue or saliva. ${ }^{1}$ Any injury to the teeth or to the periodontium area, including gums, alveolar bone, and periodontal ligament, and even the nearby soft tissues like the lips, tongue, and jawbones are considered as oral injuries. ${ }^{2,3}$ Dental trauma especially oral and maxillofacial injuries are common and part of combat sports. ${ }^{4-7}$ The injury may come from the contact between two heads, dangerous falls, clenching of tooth or any way of blows towards the face. ${ }^{8}$

The aggressiveness of offensive or defensive nature of combat sports is the main contributor to the risk of injuries. Giving strikes and blocks various part of the body and the face where a wide range of different techniques involved in full force, is the necessity in these sports. With a minimal protective gear, a hard blow to the face would contribute to a very risky experience in hazardous injuries on the face area. ${ }^{6,7,9}$ Different levels of competition would have different rules and intensity. A study on mixed martial arts sport found that professional fighters would have three times higher injury rate than amateur fighters. This is due to modification in bouts with different time allocated, 5 minutes for professional and 3 minutes for amateur. Plus, professional fighters are allowed to hit the head and body by elbow strike. ${ }^{10}$ This is supported by another study where it's found that physical load inflicted, when delivering or receiving blows would increase when the competitor's skill level increases. Plus, experienced fighters would feel more confident and comfortable to use more advanced techniques, thus exposing them to the risk of having injury more frequently. ${ }^{11,12}$

Sports mouth guards are made to reduce the risk of oral injuries and concussion during sport activities. ${ }^{13-16}$ A protective mouth guard should be tight-fitting yet comfortable, allows user to breathe, speak and swallow normally. It also should not cause gagging or irritation to the oral area. Mouth guards should be tasteless, odourless and thick enough to provide protection on the oral area against impact. ${ }^{17}$ There are three basic types of mouth guards available which are stock mouth guards that could be easily purchased over the counter, mouth formed guard or also known as boiled-and-bite mouth guards made from a thermoplastic material and lastly, and custom made or dental mouth guard that is produced by dentists either by vacuum-forming or heat-pressure lamination technique. ${ }^{17-19}$

Although there are a lot of studies on oral injury and sport, 2,20-23 but none were focusing closely on popular combat sports among university students where lots of factors may contribute to the oral injuries due to the way they played the game itself. There is also different opinion on relationship between levels of participation and prevalence of sport-related oral injuries among combat sport athletes. This study aimed to determine the prevalence of oral injuries; loosening teeth, broken teeth, broken bones, bruises on face, avulsion on lips, tongue or cheek, and dislocation of jaw; in combat sports, to check whether the sports mouth guards serve its function as it's expected, to see the awareness of using sports mouth guards by athletes during sport activities, and to examine the association between levels of participation and percentage of injury occurrence based on five universities in Malaysia.

\section{MATERIALS AND METHODS}

\section{Participants}

A total of 108 participants from 133 respondents whom were involved in sparring events at least at university level were selected for this study. Twenty-five subjects were excluded due to inconsistency in answering the questionnaire. Twenty-four of them were from University of Malaya (UM), 19 from University Putra Malaysia (UPM), 26 from National University of Malaysia (UKM), 20 from International Islamic University Malaysia (IIUM), and 19 from National Defence University of Malaysia (UPNM). Fifty-five of them were men and 53 women in which 71 of them were Malay, 16 Chinese, 15 Indians, two Ibans, and four Kadazans. The mean age of participants was $22.42 \pm 2.162$ years. Forty-seven of respondents reported Taekwondo as their major sport, 28 Silat, and 33 Karate with the mean participating of $6.86 \pm 4.18$ years. In terms of levels of participation, $40.7 \%$ engaged in university level, $20.4 \%$ in state level, $25.9 \%$ in national level, and the remaining 13\% in international level.

This study was approved by the Institutional Review Boards of University of Malaya, Malaysia (UM18/05/2018). All participants were asked for a written informed consent after an explanation of the procedure, prior to the start of the study. 


\section{Measurement and procedures}

Questionnaire consisting of 22 questions was used in this study including demographic data, combat sports involved, period and levels of participation, and whether there was any oral injuries occurred specifically loosening or fracture of teeth, broken bones, bruises and laceration on the oral area, and jaw dislocation during sport participation. Participants were asked regarding the usage of mouth guard and the reason of using and not using. Also, whether they knew and believed dental injury can be prevented by using mouth guard during sport activities. The questionnaire was pretested on 20 combat sports athletes prior to testing to ensure its clarity. Feedbacks on any difficulty of understanding and answering the questions were collected and addressed. All questionnaires and consent forms distributed through Google form and the link spread out through WhatsApp application and email address of volunteered athletes from the respective universities.

\section{Statistical analysis}

Statistical analyses were performed using SPSS for Windows, version 24. Descriptive analysis presenting frequencies and mean \pm standard deviation (SD) was applied to analyse the demographic data, injury occurrence, and use of mouth guard as well as awareness of using it during sport activities. Chi-square test for association was conducted to test the relationship/association between levels of sports participation and rate of oral injury; and Cramer's V measure was used to see the strength of association between these two variables. One-way analysis of Variance (ANOVA) and Bonferroni post-hoc test then further used to compare the means between the different levels of participation: university, state, national, and international. $p<.05$ was considered statistically significant in the interpretation of the results. Moreover, the preliminary assumptions were checked without any serious violations.

\section{RESULTS}

A total of 83 out of 108 (76.9\%) of participants reported that have been experienced oral injuries during sport activities. The distribution of different types of oral injuries is illustrated in Figure 1. Ninety-seven individuals (89.8\%) were aware that oral injury can be reduced by using mouth guard while 94 (87\%) agreed that mouth guard is important during sport activities. However, only 78 participants (72.2\%) used mouth guard during their sport activities, 71 of them used boiled-and-bite mouth guards and 7 wore custom-made mouth guards. The reasons they used mouth guards were because of the rules (74.03\%), their coach asked them to wear it (38.96\%), and for their own safety (81.82\%). The reasons for those who did not use mouth guard during their sport activities, 31 participants, were: their coach did not tell them to wear it (70.97\%), mouth guard was expensive for them (12.90\%), it was uncomfortable to wear mouth guard during activities (61.29\%), and it was not important for them to use mouth guard in their activities (58.06\%). Fifty-seven out

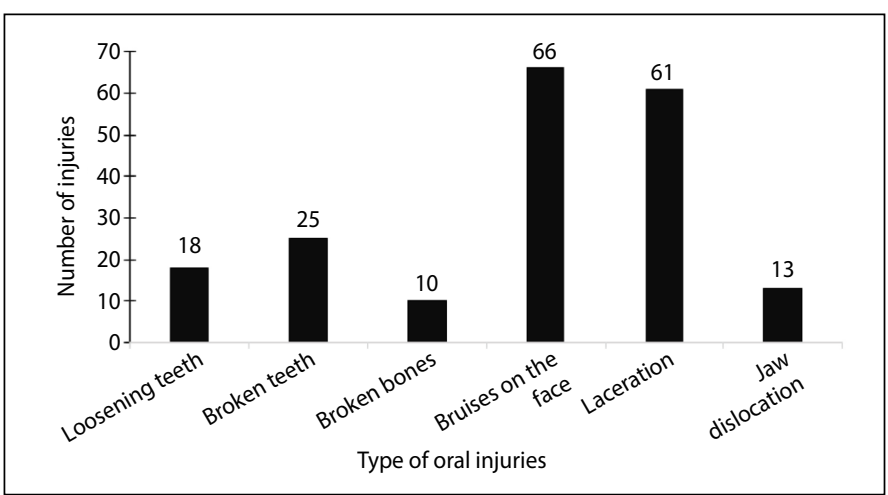

Figure 1. Prevalence of oral injury among combat sports athletes from five universities in Malaysia. of 108 participants indicated that the mouth guard is not comfortable from them to be worn during sports activities. Justification on why it's not comfortable for them is laid out in Figure 2.

Findings of Chi-square test for association (Table 1) revealed that levels of participation had a statistically significant moderate association with number of oral injuries sustained ( $p=0.013$, Cramer's $V=0.317$ ). Figure 3 illustrated the percentage of oral injuries according to levels of participation. One-way ANOVA showed a significant mean difference in rate of oral injury for the four levels of participation groups $F(3,104)$ $=6.21, p=0.011$. Post-hoc comparisons using Bonferroni test (Table 2) indicated significant mean difference between university-state levels $(p=0.033)$ and university-national levels $(p=0.028)$.

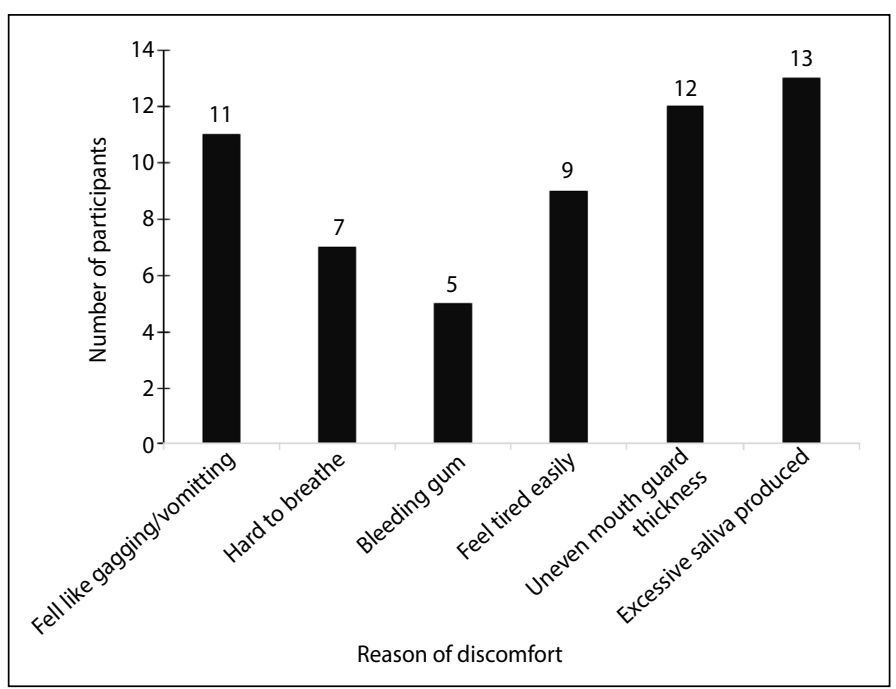

Figure 2. Reasons of discomfort in using mouth guard during sport activities.

Table 1. Pearson chi-square test analysis, the relationship between levels of participation and rate of oral injury sustained.

\begin{tabular}{|c|c|c|c|c|c|c|}
\hline \multirow[t]{2}{*}{ Oral Injury } & \multirow[t]{2}{*}{$x^{2}$} & \multicolumn{4}{|c|}{ Levels of Participation } & \multirow[t]{2}{*}{ Total } \\
\hline & & University & State & National & International & \\
\hline \multirow[t]{2}{*}{ Yes } & Count & 27 & 20 & 25 & 11 & 83 \\
\hline & Expected count & 33.8 & 16.9 & 21.5 & 10.8 & 83.0 \\
\hline \multirow[t]{3}{*}{ No } & Count & 17 & 2 & 3 & 3 & 25 \\
\hline & Expected count & 10.2 & 5.1 & 6.5 & 3.2 & 25.0 \\
\hline & & 44 & 22 & 28 & 14 & 108 \\
\hline
\end{tabular}

* Only university level showed lower number of oral injury experienced whereas the others showed more than the expected outcome.

Table 2. Bonferroni post-hoc test for rate of oral injury between the levels of participation.

\begin{tabular}{c|c|c}
\hline Levels of Participation (I) & Levels of Participation (J) & Sig. \\
\hline University & State & 0.033 \\
\hline & National & 0.028 \\
\hline State & International & 0.517 \\
\hline National & National & 0.999 \\
\hline *Significant One-way ANOVA test $(p=0.011)$ & International & 0.813 \\
\hline
\end{tabular}

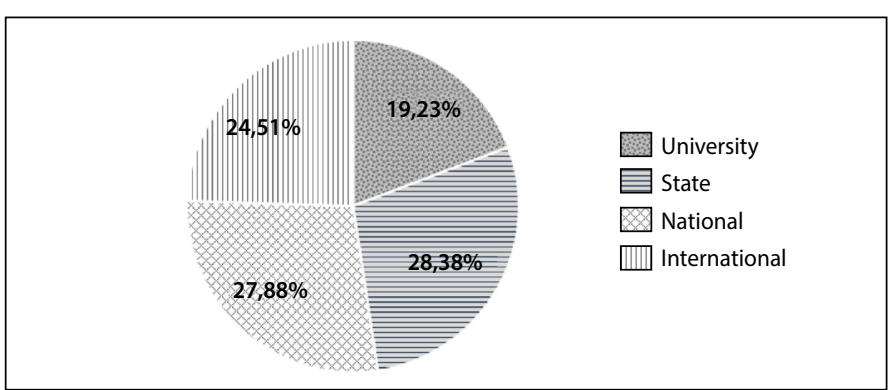

Figure 3. Percentage of oral injuries according to levels of participation. 


\section{DISCUSSION}

Results of the study showed that the awareness of using mouth guard as a protective gear in Malaysian combat sports athletes is high (very close to 90\%); however, the prevalence of oral injuries is still high with nearly $77 \%$ occurrence. Bruises on the face were the highest reported cases followed by laceration, and the least was broken bones. However, in previous studies, laceration was the highest reported cases. ${ }^{5,724}$ This is possible due to modification of rules and changes in game play. When the audience think matches started to get boring, rules are modified to increase the intensity and make it more interesting. For example, World Taekwondo Federation (WTF) changed the fighting time from three minutes per round to two minutes per round, a point will be deducted when there is inaction after 10 seconds during a match, and reintroduction of more points for head kicks. ${ }^{25}$ Thus, this promotes more aggressiveness and contusion which leads to bruises instead of laceration. For the type of oral injuries, we also focus on jaw dislocation though the questionnaire that we adopted did not look into it. The reason we took it into account is because protecting the jaws to avoid concussion injury is one of mouth guards'function. ${ }^{14,15}$ There are still jaw injuries even though athletes wear a mouth guard during sport activities. This could happen due to the type of mouth guards they used which might not be protective enough to protect the jaw. As is found from our study, out of 78 athletes who wore mouth guards, 91\% used boiled-and-bite mouth guards and only $9 \%$ wore custom-made mouth guards. It's found that boiled-and-bite mouth guard has lesser protection and retention due to lack of proper extension and thickness ${ }^{17,26}$ which reduce the protective function where a mouth guard should really serve.

More than $60 \%$ of participants who did not use mouth guards during sports activities complained that the mouth guard is not comfortable to be used during sports activities. This is because the mouth guard that they tried, did not meet the specifications that has been made which it has to be tight-fitting, allows user to breathe, speak and swallow normally, and does not cause gagging or irritation to the oral part.17,27 Production of excessive saliva, thickness of mouth guard at all the wrong place, bleeding gum, and difficulty of breathing would not be the issues if they use a proper mouth guard. Although boiled-and-bite mouth guards has all of these characteristics where it fits poorly, has a poor retention, and gives gagging effects to the user, still, over $90 \%$ of the participants used boiled-and-bite mouth guards since it has been proven to be the most popular among all sports mouth guards. ${ }^{17,18}$ Only $9 \%$ used custom-made mouth guard though it is the most protective among all. This is may be due to lack of knowledge about this type of mouth guard as it's seen half of the participants did not know about custom-made mouth guard. Another reason might be getting a custom-made mouth guard is costly as it requires a dentist or dental technician to make it from specific materials through specific techniques. ${ }^{18,26,28}$

Percentage of injuries for state and national level are quite close with $28.38 \%$ and $27.88 \%$, respectively, followed by international level with $24.51 \%$, and university level $19.23 \%$. Previous study found that athletes representing their universities would have the lowest sport performance due to higher competitive anxiety compared to the higher level athletes. ${ }^{29}$ Higher level athletes would have a better skill with a higher physical load inflicted on their body as they deliver or receive blows. Experience fighters are likely to expose frequently to more dangerous techniques as they are comfortable to use them during their fights. ${ }^{11,12}$ Based on our findings, it's proven that higher level athletes have a higher chance of getting oral injuries with a significant difference found through chi-square test and one-way ANOVA. However, we also found that at international level, Malaysian athletes were not getting much oral injuries. This might be because of Malaysian athletes would not survive long as in the chances of them getting into the next round is lower at international games. Basically, Asian kinanthropometric attributes are much smaller in terms of body size, proportions, shape, body composition and physic when compared to European and others and this is highly related to sports performance. ${ }^{30}$

\section{CONCLUSION}

In summary, this study revealed that higher levels of participation in sport would have a higher risk of getting injuries. Significant result was found when comparing the percentage of injury between university with state and national levels. Cost is not the main reason athletes do not wear mouth guards. In fact, coaches are the one who play a bigger role in making the athletes to use it. Although boiled-and-bite mouth guard is the most popular and most chosen one, it is not the best mouth guard to be used by the athletes to protect their oral area. The uncomfortable feeling of using mouth guard can be reduced if the athletes wear a proper mouth guards that follows the specifications that has been made. Coaches and dental technician should emphasize more on a proper mouth guard usage to reduce the incident of oral injury during sports activities. The limitation of this study is all types of mouth guards used, are counted and the way participants used the mouth guard cannot be controlled as they might alter the mouth guard to make it more comfortable yet reduces the function of the mouth guard as a protective gear. Therefore, future studies might want to focus on only custom-made mouth guards and the prevalence of injury since it is the best sports mouth guards in terms of protection.

All authors declare no potential conflict of interest related to this article

AUTHORS'CONTRIBUTIONS: Each author made significant individual contributions to this manuscript. MH: preparation of the entire research project, study supervision, and critical revision of the intellectual content of the manuscript; IDA: data collection, initial data analysis and interpretation, and writing the draft of the manuscript; HM: statistical analysis and interpretation, and critical revision of the manuscript; EH: research design and supervision; YS: interpretation of results and revision of manuscript; MDA: data collection and writing the draft of the manuscript. All authors read and approved the final manuscript.

\section{REFERENCES}

1. Spinas E, Giannetti L, Mameli A, Re D. Dental injuries in young athletes, a five-year follow-up study. Eur J Paediatr Dent. 2018;19(3):187-93.

2. Gould TE, Piland SG, Caswell SV, Ranalli D, Mills S, Ferrara MS, et al. National Athletic Trainers' Association Position Statement: Preventing and Managing Sport-Related Dental and Oral Injuries. J Athl Train. 2016;51(10):821-39.

3. Piccininni P, Clough A, Padilla R, Piccininni G. Dental and Orofacial Injuries. Clin Sports Med. 2017;36(2):369-405.

4. Bromley SJ, Drew MK, Talpey S, McIntosh AS, Finch CF. A systematic review of prospective epidemiological research into injury and illness in Olympic combat sport. Br J Sports Med. 2018;52(1):8-16.

5. Hojjat H, Svider PF, Lin HS, Folbe AJ, Shkoukani MA, Eloy JA, et al. Adding Injury to Insult: A National
Analysis of Combat Sport-Related Facial Injury. Ann Otol Rhinol Laryngol. 2016;125(8):652-9.

6. Polmann H, Melo G, Conti Réus J, Domingos FL, de Souza BDM, Padilha AC, et al. Prevalence of dentofacial injuries among combat sports practitioners: A systematic review and meta-analysis. Dent Traumatol. 2020;36(2):124-40.

7. Shirani G, Kalantar Motamedi MH, Ashuri A, Eshkevari PS. Prevalence and patterns of combat sport related maxillofacial injuries. J Emerg Trauma Shock. 2010;3(4):314-7.

8. Tsuchiya S, Tsuchiya M, Momma H, Sekiguchi T, Kuroki K, Kanazawa K, et al. Factors associated with sports-related dental injuries among young athletes: a cross-sectional study in Miyagi prefecture. BMC Oral Health. 2017;17(1):168.

9. Oliveira Werlich M, Honnef LR, Silva Bett JV, Domingos FL, Pauletto P, de Souza BDM, et al. Prevalence 
of dentofacial injuries in contact sports players: a systematic review and meta-analysis. Dent Traumatol. 2020;36(5):477-88.

10. Rainey CE. Determining the prevalence and assessing the severity of injuries in mixed martial arts athletes. N Am J Sports Phys Ther. 2009;4(4):190-9.

11. Kazemi M, Chudolinski A, Turgeon M, Simon A, Ho E, Coombe L. Nine year longitudinal retrospective study of Taekwondo injuries. J Can Chiropr Assoc. 2009;53(4):272-81.

12. Lystad RP. Injuries to Professional and Amateur Kickboxing Contestants: A 15-Year Retrospective Cohort Study. Orthop J Sports Med. 2015;3(11):2325967115612416.

13. ADA Council on Access, Prevention and Interprofessional Relations; ADA Council on Scientific Affairs. Using mouthguards to reduce the incidence and severity of sports-related oral injuries. J Am Dent Assoc. 2006;137(12):1712-31.

14. Green JI. The Role of Mouthguards in Preventing and Reducing Sports-related Trauma. Prim Dent J. 2017;6(2):27-34.

15. Knapik JJ, Hoedebecke BL, Rogers GG, Sharp MA, Marshall SW. Effectiveness of Mouthguards for the Prevention of Orofacial Injuries and Concussions in Sports: Systematic Review and Meta-Analysis. Sports Med. 2019;49(8):1217-32.

16. Spinas E, Mameli A, Giannetti L. Traumatic Dental Injuries Resulting from Sports Activities; Immediate Treatment and Five Years Follow-Up: An Observational Study. Open Dent J. 2018;12:1-10.

17. Parker K, Marlow B, Patel N, Gill DS. A review of mouthguards: effectiveness, types, characteristics and indications for use. Br Dent J. 2017;222(8):629-33.

18. Tuna EB, Ozel E. Factors affecting sports-related orofacial injuries and the importance of mouthguards. Sports Med. 2014;44(6):777-83.

19. Zamora-Olave C, Willaert E, Montero-Blesa A, Riera-Punet N, Martinez-Gomis J. Risk of orofacia injuries and mouthguard use in water polo players. Dent Traumatol. 2018;34(6):406-12.
20. Aljohani YR, Alfaifi KH, Redwan SK, Sabbahi DA, Zahran MH. Dental injuries in taekwondo athletes practicing in Saudi Arabia. Saudi Med J. 2017;38(11):1143-7.

21. Fitzpatrick DG, Goh M, Howlett DC, Williams M. Bicycle helmets are protective against facial injuries, including facial fractures: a meta-analysis. Int J Oral Maxillofac Surg. 2018;47(9):1121-5.

22. Qudeimat MA, AlHasan AA, AlHasan MA, Al-Khayat K, Andersson L. Prevalence and severity of traumatic dental injuries among young amateur soccer players: A screening investigation. Dent Traumatol. 2019;35(4-5):268-75.

23. Vidovic D, Bursac D, Skrinjaric T, Glavina D, Gorseta K. Prevalence and prevention of dental injuries in young taekwondo athletes in Croatia. Eur J Paediatr Dent. 2015;16(2):107-10.

24. Armed Forces Health Surveillance Center (AFHSC). Injuries associated with combat sports, active component, U.S. Armed Forces, 2010-2013. MSMR. 2014;21(5):16-8.

25. Moenig U. Rule and equipment modification issues in World Taekwondo Federation (WTF) competition Ido Mov Culture. J Martial Arts Anthrop. 2015;15(4):3-12

26. Patrick DG, van Noort R, Found MS. Scale of protection and the various types of sports mouthguard. Br J Sports Med. 2005;39(5):278-81.

27. Knapik JJ, Marshall SW, Lee RB, Darakjy SS, Jones SB, Mitchener TA, et al. Mouthquards in Sport Activities History, Physical Properties and Injury Prevention Effectiveness. Sports Med. 2007;37(2):117-44.

28. Allison P, Tamimi F. Mouthguards should be worn in contact sports. Br J Sports Med. 2020;54:1016-7

29. Parnabas VA, Mahamood Y. Competitive anxiety level before and during competition among Malaysian athletes. Pertanika J Soc Sci Hum. 2010;18(2):399-406

30. Andrade A, Flores MA, Andreato LV, Coimbra DR. Physical and Training Characteristics of Mixed Martial Arts Athletes: Systematic Review. Strength Cond J. 2019;41(1):51-63. 